\title{
STRATEGI PENUNJANG ADOPSI TEKNOLOGI M-COMMERCE B2C DI INDONESIA (LAZADA, ZALORA DAN BHINNEKA)
}

\author{
Lady Joanne Tjahyana \\ Program Studi Ilmu Komunikasi, Fakultas Ilmu Komunikasi, Universitas Kristen Petra \\ Jl. Siwalankerto 121-131, Surabaya 60236, INDONESIA \\ e-mail: joanne@petra.ac.id
}

\begin{abstract}
ABSTRAK
Indonesia merupakan negara dengan pertumbuhan pengadopsi mobile commerce (m-commerce) signifikan di Asia Tenggara seiring dengan tingkat pertumbuhan penyedia layanan m-commerce teutama pada sektor Business to Consumer (B2C) di Indonesia. Layanan $m$-commerce di Indonesia tersedia dalam bentuk aplikasi mobile maupun mobile friendly version dari website e-commerce yang telah ada. Melihat tingkat pertumbuhan adopsi $m$-commerce $\mathrm{B} 2 \mathrm{C}$ tersebut maka penelitian ini dilakukan untuk mengetahui strategi apa yang dilakukan oleh penyedia layanan $m$-commerce $\mathrm{B} 2 \mathrm{C}$ di Indonesia untuk menunjuang faktor adopsi teknologi m-commerce tersebut. Penelitian dilakukan dengan metode analisis isi kulatitatif deskriptif menggunakan faktor adopsi m-commerce yaitu trust, cost, social influences, variety of services, perceived usefulness, perceived ease of use, dan trialability. Objek penelitian adalah 3 toko online B2C terpopuler di Indonesia dengan ranking Alexa di bawah 100 yaitu Lazada, Zalora, dan Bhinneka. Dari hasil penelitian ini dapat disimpulkan bahwa ketiga toko online tersebut memiliki dan menerapkan strategi-strategi untuk menunjang faktor adopsi $m$-commerce pada aplikasi mobile maupun mobile friendly version dari website e-commerce.
\end{abstract}

Kata kunci: m-commerce, $B 2 C$, Aplikasi mobile, adopsi.

\begin{abstract}
Indonesia is a country with significant amount of mobile commerce (m-commerce) users in Asia Pasific, supported by the growth of m-commerce providers especially in Business to Consumer (B2C) sector. The m-commerce services in Indonesia are availabe on mobile application and mobile friendly version of the e-commerce websites. This research was conducted to see the strategies being used by the m-commerce providers to support the factors of m-commerce adoption in Indonesia. The method used in this research was qualitative content analysis using m-commerce adoption factors, which are trust, cost, social influences, variety of services, perceived usefulness, perceived ease of use, and trialability. The objects of this research are the top 3 of the most popular B2C online shops in Indonesia with Alexa Rank below 100. Those online shops are Lazada, Zalora and Bhinneka. The conclusion of this research was that those B2C online shops have applied their strategies to support the m-commerce adoption factors on mobile applications as well as on mobile friendly version of their e-commerce websites.
\end{abstract}

Keywords: m-commerce, B2C, mobile application, adoption.

\section{PENDAHULUAN}

Indonesia merupakan negara dengan jumlah pengadopsi teknologi e-commerce dan mobile commerce (m-commerce) yang signifikan di Asia Pasifik, khususnya dalam sektor Business to Consumer (B2C). Menurut hasil survey dan prediksi yang di lakukan oleh Emarkerter, maka Indonesia merupakan salah satu negara yang memiliki tingkat pertumbuhan B2C melalui E-Commerce terbesar di Asia Pasifik, yaitu menduduki peringkat kedua setelah China. Bahkan diprediksi bahwa tingkat pertumbuhan ini akan terus bertambah hingga tahun 2017 (Emarkerter, 2014). Selain itu menurut sebuah laporan dari lembaga riset yStats, yang berjudul "Southeast Asia B2C E-Commerce Market 2015" Indonesia merupakan negara yang memiliki sumbangsih lebih dari sepertiga penjualan B2C di Asia Tenggara (yStats, 2015). Lebih lanjut menurut laporan yStats yang berjudul "Asia Pacific M-Commerce Snapshot 2015', Indonesia memiliki tingkat penetrasi belanja mobile tertinggi kedua setelah Singapore di Asia Tenggara (yStats, 2015).

Meningkatnya pertumbuhan adopsi e-commerce khususnya m-commerce di Indonesia, juga diiringi dengan berkembangnya fasilitas berupa aplikasi $m$ commerce maupun mobile friendly version dari website e-commerce yang ada di Indonesia. Menurut Techinasia (2014), terdapat 6 toko online populer di Indonesia yang bergerak dalam sektor B2C, yaitu Lazada Indonesia, Bhinneka, Agoda, Zalora Indo- 
nesia, Tiket dan Groupon Indonesia. Keenam toko online atau penyedia layanan e-commerce tersebut telah memiliki aplikasi mobile dan mobile friendly version untuk website e-commerce.

Menurut Rogers (2010), faktor penunjang kecepatan adopsi sebuah inovasi atau yang disebut sebagai rate of adoption terutama ditentukan oleh kelima atribut dari inovasi itu sendiri yaitu: relative advantage, compatibility, complexity, trialability, dan observability.

Penelitian terdahulu mengenai adopsi teknologi $m$ commerce telah dilakukan oleh Chong, Chan, \& Ooi (2012), yang bertujuan untuk memprediksi keputusan pelanggan dalam mengadopsi m-commerce di China dan Malaysia. Dalam penelitian tersebut, Chong, Chan, \& Ooi (2012) menggabungkan atribut inovasi Everett dengan model technology acceptance model (TAM) serta beberapa faktor lainnya sebagai faktor yang mempengaruhi adopsi m-commerce yaitu trust, cost, social influences, variety of services, perceived usefulness, perceived ease of use, dan trialability.

Melihat data adopsi m-commerce di Indonesia serta berkembangnya aplikasi m-commerce tersebut peneliti tertarik untuk melihat strategi yang dipakai oleh penyedia layanan $m$-commerce untuk menarik minat pengguna dalam mengadopsi teknologi tersebut.

\section{TINJAUAN PUSTAKA}

\subsection{Diffusion of Innovation}

Menurut Rogers (2010), diffusion of innovation atau difusi inovasi adalah sebuah proses di mana sebuah inovasi dikomunikasikan melalui beberapa channels atau saluran dalam jangka waktu tertentu di dalam sebuah sistem sosial. Agar sebuah inovasi dapat diterima dan diadopsi tentunya tidak mudah, meskipun inovasi tersebut memiliki manfaat yang nyata. Banyak inovasi yang memerlukan waktu yang lama untuk dapat diadopsi secara luas, sehingga permasalahan umum yang timbul dalam difusi inovasi adalah bagaimana mempercepat adopsi sebuah inovasi.

Ada beberapa tahap dalam difusi inovasi yaitu knowledge, persuasion, decision, implementation, dan confirmation.

Atribut dari inovasi itu sendiri yaitu: relative advantage, compatibility, complexity, trialability, dan observability, juga merupakan faktor penunjang rate of adoption atau kecepatan adopsi sebuah inovasi. (Rogers, 2010)

\subsection{Technology Acceptance Model}

Salah satu model yang telah digunakan secara umum untuk melihat proses penerimaan atau adopsi dari sebuah inovasi di bidang teknologi Informasi adalah Technology Acceptance Model (TAM). Model ini diperkenalkan oleh Davis (1989), dan terdiri dari 2 faktor utama yaitu perceived of usefulness dan perceived ease of use. (Oh \& Yoon, 2014)

\subsection{Faktor Yang Mempengaruhi Adopsi M-Com- merce}

Meskipun diffusion of innovation dan technnological accpetance model telah dapat merepresentasikan proses dan perilaku adopsi dari pengguna, tetapi menurut Oh \& Yoon (2014) kedua model tersebut tidak memperhitungkan karakteristik dari teknologi inovasi tersebut. Oleh karena itu Chong, Chan, \& Ooi (2012) menggabungkan diffusion of innovation dan technological acceptance model serta menambah beberapa elemen yang merupakan karakteristik khusus dari m-commerce dalam menentukan faktor faktor yang mempengaruhi adopsi teknologi $m$ commerce. Faktor - faktor tersebut adalah trust, cost, social influences, variety of services, perceived usefulness, perceived ease of use, dan trialability.

\subsubsection{Trust}

Menurut Chong, Chan, \& Ooi (2012), perlu untuk diketahui apakah trust merupakan faktor yang dapat mempengaruhi pengguna dalam mengadopsi $\mathrm{m}$ commerce. Penelitian yang dilakukan oleh Chong, Chan, \& Ooi (2012) menggunakan faktor trust untuk mengetahui apakah pengguna bersedia untuk mengambil resiko dalam mengadopsi $m$-commerce, meskipun dalam penggunaan $m$-commerce terdapat resiko dari segi security dan privacy. Selain itu transaksi yang dilakukan dengan teknologi m-commerce tidak memungkinkan terjadinya interaksi secara face to face dengan penyedia layanan m-commerce. Sehingga pengguna harus dapat mempercayakan keamanan dan privacy data yang ditransfer pada saat melakukan transaksi m-commerce. Hal ini terutama sangat penting dalam transaksi m-commerce B2C di mana pembeli harus dapat mempercayai penyedia layanan m-commerce sepenuhnya dalam melakukan transaksi. (Chong, Chan, \& Ooi, 2012)

\subsubsection{Cost}

Pada penelitian faktor adopsi pengguna $m$-commerce di Malaysia perlu untuk diuji apakah faktor cost atau 
biaya dapat memiliki pengaruh dalam adopsi inovasi seperti teknologi m-commerce. Hal ini disebabkan karena harga teknologi smartphone yang semakin tinggi, dan untuk mengadopsi $m$-commerce diperlukan teknologi smartphone terkini yang dapat menunjang penggunaan m-commerce tersebut. Faktor cost terutama dapat berpengaruh pada pengguna di kalangan pelajar yang masih belum memiliki penghasilan yang tinggi (Chong, Chan, \& Ooi, 2012).

\subsubsection{Social Influence}

Social Influence merupakan faktor adopsi tingkat kebutuhan pengguna untuk mengadopsi yang dipengaruhi oleh pendapat orang-orang di lingkungan sekitarnya tentang seberapa perlu pengguna mengadopsi sebuah inovasi. Dalam mengadopsi sebuah inovasi, lingkungan sekitar seperti teman, rekan kerja maupun keluarga dapat memberikan pengaruh dalam proses adopsi. Media juga memegang peranan penting, terutama media interaktif seperti jejaring sosial, online games ataupun komunitas-komunitas online lainnya. Oleh karena itu menarik untuk diketahui apakah social influence dapat mempengaruhi pengguna dalam mengadopsi teknologi m-commerce. (Chong, Chan, \& Ooi, 2012)

\subsubsection{Variety of Services}

Karena m-commerce dilakukan menggunakan mobile devices maka tentunya akan terdapat limitasi dalam layanan atau variety of services yang diberikan jika dibandingkan dengan e-commerce. Namun aplikasi $m$-commerce yang ada tentunya telah semakin meningkatkan pelayanan yang diberikan dalam bentuk fitur-fitur yang bermanfaat seperti pembayaran mobile banking, fitur berbagi dalam social media, fitur musik dan video, serta fitur permainan. Sehingga perlu diketahui apakah variety of services merupakan faktor yang dapat mempengaruhi seseorang dalam mengadopsi teknologi m-commerce. (Chong, Chan, \& Ooi, 2012)

\subsubsection{Perceived Usefulness}

Dalam pengadopsian inovasi teknologi, faktor perceived usefulness atau kegunaan yang diterima oleh pengguna memegang peranan yang penting. $M$ commerce memiliki beberapa manfaat lebih dibanding e-commerce seperti mobilitas dalam bertransaksi tanpa dibatasi ruang dan waktu. Selain itu pengguna cukup menggunakan gadget yang lebih praktis seperti smartphone dibandingkan jika harus membawa laptop yang lebih berat dari segi dimensi dan ukuran.
Melihat kegunaan yang didapat tersebut, maka Chong, Chan, \& Ooi, 2012 melihat perlu untuk diketahui apakah faktor perceiced usefulness tersebut memang berpengaruh dalam proses adopsi $\mathrm{m}$-commerce. (Chong, Chan, \& Ooi, 2012).

\subsubsection{Perceived Ease of Use}

Teknologi m-commerce memiliki tantangan tersendiri dalam memberikan kemudahan penggunaan teknologi tersebut. Hal ini dikarenakan adanya batasan batasan yang disebabkan oleh berbagai macam limitasi pada mobile device seperti ukuran layar yang kecil dan kesulitan untuk mengetik huruf dapat menjadi halangan bagi pengguna untuk mengadopsi $m$-commerce. Selain itu banyak pula fitur dan fungsi yang dihilangkan agar tidak memberatkan proses kerja aplikasi m-commerce. Melihat berbagai macam limitasi tersebut, maka faktor perceived ease of use tersebut dapat dijadikan salah satu indikator penentu keputusan pengguna untuk mengadopsi $m$-commerce. (Chong, Chan, \& Ooi, 2012).

\subsubsection{Trialability}

Adanya kesempatan untuk mencoba aplikasi dan merasakan manfaat aplikasi tersebut secara gratis dapat mempengaruhi pengguna dalam mengadopsi sebuah inovasi teknologi. Terutama dalam teknologi $m$-commerce maka beberapa fitur yang bersentuhan dengan faktor trust seperti keamanan dan privacy maka kesempatan untuk mencoba terlebih dahulu sebelum mengadopsi akan menjadi faktor penunjang adopsi oleh pengguna. (Chong, Chan, \& Ooi, 2012).

\section{METODE PENELITIAN}

Metode penelitian yang dipakai adalah analisis isi kualitatif deskriptif. Penelitian serupa dengan topik $m$ commerce di Indonesia telah dilakukan oleh Utami \& Triyono (2011), yaitu penelitian tentang pemanfaatan Blackberry sebagai sarana komunikasi dan penjualan batik online dengan sistem dropship di Batik Solo 85. Penelitian tersebut menggunakan analisis isi kualitatif deskriptif karena penelitian dilakukan dengan teliti untuk menggambarkan dan mendeskripsikan secara detil dari suatu peristiwa yang terjadi.

Penelitian ini dilakukan secara kualitatif deskriptif dengan menganalisa fitur-fitur dari aplikasi $m$ commerce yang ada di Indonesia. Adapun aplikasi $m$ commerce yang dipilih adalah aplikasi mobile dari website B2C terpopuler di Indonesia menurut Techinasia, yang menyediakan layanan penjualan barang 
kepada pengguna serta memiliki ranking Alexa di bawah 100 untuk Indonesia hingga pada saat penelitian ini dilakukan. Aplikasi yang dipilih adalah aplikasi Lazada, Bhinneka, dan Zalora (Lukman, 2014).

Untuk mengetahui strategi penunjang adopsi aplikasi m-commerce yang disediakan oleh ketiga aplikasi website B2C terpopuler di Indonesia tersebut, maka analisa dilakukan menggunakan faktor - faktor adopsi teknologi yang digunakan oleh Chong, Chan, \& Ooi, 2012 dalam penelitian mereka tentang adopsi $\mathrm{m}$ commerce di China dan Malaysia. Adapun pertanyaan-pertanyaan yang digunakan untuk menganalisa adalah:

- Strategi apa yang digunakan untuk menunjang faktor trust dalam adopsi aplikasi ?

- Strategi apa yang digunakan untuk menunjang faktor cost dalam adopsi aplikasi ?

- Strategi apa yang digunakan untuk menunjang faktor social influence dalam adopsi aplikasi ?

- Strategi apa yang digunakan untuk menunjang faktor variety of services dalam adopsi aplikasi ?

- Strategi apa yang digunakan untuk menunjang faktor perceived of usefulness dalam adopsi aplikasi ?

- Strategi apa yang digunakan untuk menunjang faktor perceived ease of use dalam adopsi aplikasi ?

- Strategi apa yang digunakan untuk menunjang faktor trialability dalam adopsi aplikasi ?

\section{HASIL DAN PEMBAHASAN}

\subsection{Trust}

Untuk mendapatkan kepercayaan pengguna dalam mengadopsi teknologi m-commerce maka berbagai strategi telah dilakukan. Strategi yang dilakukan oleh Zalora adalah dengan memberikan informasi mengenai Zalora Indonesia melalui menu "Tentang Kami" pada aplikasi m-commerce. Selain itu pada aplikasi Lazada dan Zalora terdapat pula menu "Kebijakan Privasi" di mana pada menu tersebut dijelaskan mengenai pernyataan privasi Lazada dan Zalora yang menganggap serius privasi pelanggan khususnya dalam hal pengumpulan informasi personal, keamanan informasi pribadi, penyingkapan informasi pribadi hingga pengumpulan data komputer seperti IP address dan statistik pengguna. Jika terdapat keluhan pelanggaran privasi, maka pengguna dapat menghubungi pihak Zalora melalui email.
Untuk menjaga keamanan dan kenyamanan pengguna Lazada, pada aplikasi m-commerce terdapat menu "Syarat \& Ketentuan" yang memberikan ketentuan penggunaan aplikasi kepada pengguna. Syarat dan ketentuan ini diberikan agar aplikasi digunakan sebagaimana mestinya oleh pengguna sehingga tidak mengganggu kenyamanan, privasi, dan keamanan pengguna lainnya. Lebih lanjut untuk meraih kepercayaan pengguna, Lazada menyertakan logo Perlindungan Pembeli 100\% dan logo Jaminan Kepuasan pada produk - produk yang dijual seperti yang terlihat pada gambar 1. Pada gambar 1 tersebut terlihat adanya logo - logo tersebut pada kolom detil supplier yang menjual sebuah produk, sehingga pengguna merasa yakin akan produk beserta penjualnya. Perlindungan tersebut menyatakan bahwa produk tersebut berada dalam jaminan $100 \%$ yang menawarkan garansi retur 7 hari, garansi uang kembali dan layanan seller yang telah diverifikasi oleh Lazada.

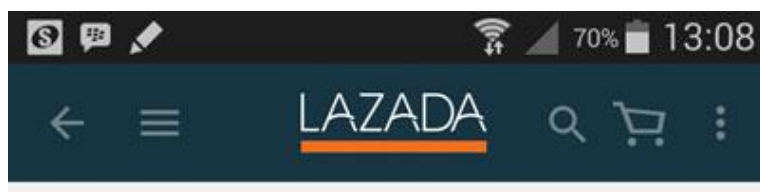

Samsung Galaxy S6 Edge+ - 64 GB - Gold PI...

\section{Detil Supplier}

Dijual oleh Lazada

Kebijakan Pengembalian Barang Gratis

$100 \%$ jaminan asli

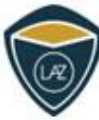

PERLINDUNGAN PEMBELI $100 \%$

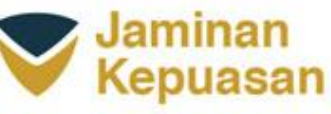

Informasi Garansi

1 Tahun Garansi Resmi Samsung

Anda Mungkin Juga Suka

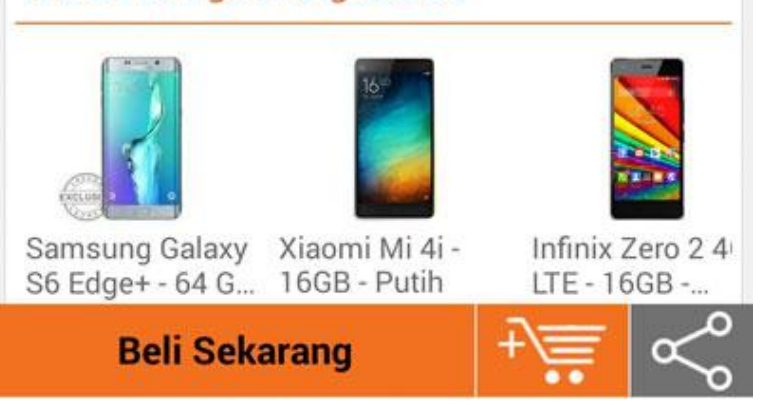

Gambar 1. Perlindungan Pembeli 100\% Lazada 
Demikian pula dengan aplikasi Bhinneka yang menyediakan menu "Contact Us" yang terdiri dari "Contact Center", "Service Center" dan, "SMS Center" serta "Email". Menu tersebut tentunya akan memberikan jaminan kepercayaan kepada pengguna aplikasi bahwa pihak Bhinneka mudah untuk dihubungi dan bertanggung jawab terhadap kerusakan barang. Terdapat pula menu "Legal Information" yang memberikan pernyataan bahwa aplikasi tersebut memang milik dan tanggung jawab dari PT. Bhinneka Mentari Dimensi.

\subsection{Cost}

Cost atau biaya adalah salah satu faktor yang cukup menjadi perhatian para penyedia layanan $m$ commerce di Indonesia, yang berlomba-lomba menarik minat pengguna untuk mengadopsi teknologi $m$ commerce mereka. Baik Lazada, Bhinneka maupun Zalora telah berlomba-lomba untuk menyediakan potongan harga bagi pengguna sebagai strategi untuk menarik minat pengguna m-commerce. Salah satu strategi yang dipakai oleh Zalora adalah disediakannya diskon khusus bagi pengguna yang bersedia untuk download dan install aplikasi m-commerce mereka. Diskon yang diberikan yaitu Rp.100.000,untuk pembelian minimal IDR Rp.300.000,- bagi pembelian pertama melalui aplikasi Zalora, dengan cara menyertakan kode diskon ZAPP100, seperti yang terlihat pada gambar 2. Pada gambar tersebut terlihat adanya pop up window dan tombol untuk dapat langsung mengunduh dan menginstal aplikasi tersebut.

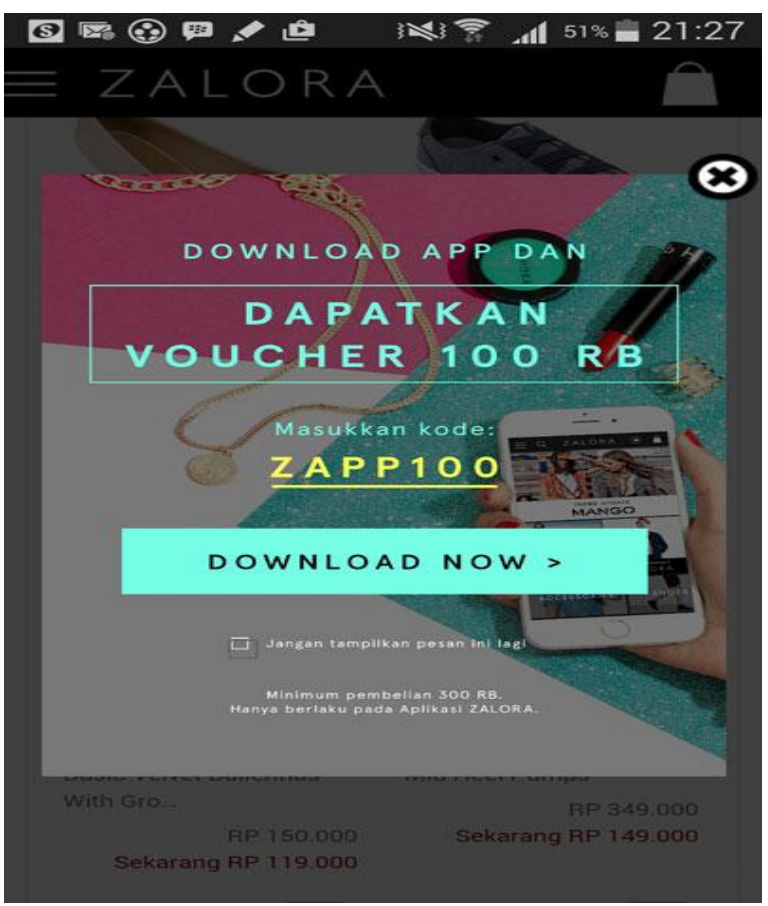

Gambar 2. Diskon Aplikasi Zalora
Selain itu, Lazada dan Zalora memberikan voucher khusus bagi pengguna yang bersedia untuk subscribe pada layanan newsletter. Hal ini tentunya akan menarik minat pengguna untuk subscribe dan menerima informasi seputar promosi yang ada pada inbox email. Bagi pengguna mobile device yang membaca email tersebut dapat langsung klik pada tautan promosi dan secara otomatis diarahkan untuk membuka website versi mobile pada browser mobile device pengguna. Binneka juga memberikan diskon khusus berupa e-coupon bagi pengguna yang bersedia untuk mendaftar menjadi member. Lebih lanjut juga terdapat sistem point reward bagi setiap pembelian yang dilakukan oleh member.

Baik pada tampilan mobile friendly website ataupun pada tampilan aplikasi m-commerce, Lazada, Zalora, dan Bhinneka selalu menampilkan promosi dan diskon yang sedang berlangsung pada saat itu. Khususnya pada aplikasi Lazada dan Zalora, terdapat notifikasi yang akan muncul pada layar mobile device pengguna mengenai promosi dan diskon serta program - program potongan lainnya.

\subsection{Social Influence}

Dalam menunjang faktor adopsi social influence, Lazada, Zalora dan Bhinneka telah menerapkan beberapa strategi yang dapat mempengaruhi pengguna untuk mengadopsi teknologi $m$-commerce yang disediakan. Strategi yang diterapkan adalah menggunakan fitur Product Review serta Rating dan Ulasan pada aplikasi di mana pengguna dapat melihat ulasan atau review produk dari para pembeli yang juga adalah member mengenai produk terkait. Demikian pula pengguna dapat melihat rating dari pembeli tentang kualitas dari produk tersebut.

Lebih lanjut, Bhinneka juga menyediakan fitur "Share" untuk berbagi produk tersebut pada social media seperti Facebook, Twitter dan Google +. Pengguna juga dapat mengirim tautan produk tersebut melalui email kepada teman yang membutuhkan seperti terlihat pada gambar 3. Pada gambar tersebut terlihat adanya pilihan-pilihan media sosial seperti Facebook, Twitter, dan Google +. Terdapat pula pilihan untuk berbagi lewat email. Fitur berbagi ini tentunya akan meningkatkan visibilitas produk pada social media yang akan menunjang faktor social influence dalam adopsi teknologi m-commerce yang disediakan oleh Bhinneka.

Selanjutnya, Lazada, Zalora dan Bhinneka juga telah memanfaatkan fitur iklan pada social media untuk menarik perhatian para pengguna social media untuk mengadopsi teknologi m-commerce. 


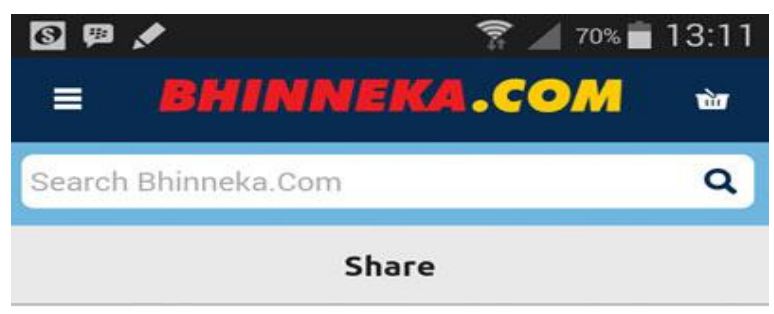

SAMSUNG Galaxy Tab S2 8.0" - Gold

Tablet Android

Bhinneka Part No : SKU06115813

\begin{tabular}{l}
\hline Facebook \\
\hline+ Twitter \\
\hline+ Email
\end{tabular}

Gambar 3. Fitur Share Bhinneka

Sebagai contoh adalah iklan dari Lazada pada social media Instagram yang dapat dilihat pada gambar 4. Pada gambar tersebut terlihat adanya iklan barang elektronik di mana terdapat tombol learn more untuk langsung dihubungkan pada info produk. Selain itu baik Lazada, Zalora maupun Bhinneka juga memiliki akun media sosial sebagai tempat bagi member, pembeli, dan calon pembeli untuk saling berbagi.
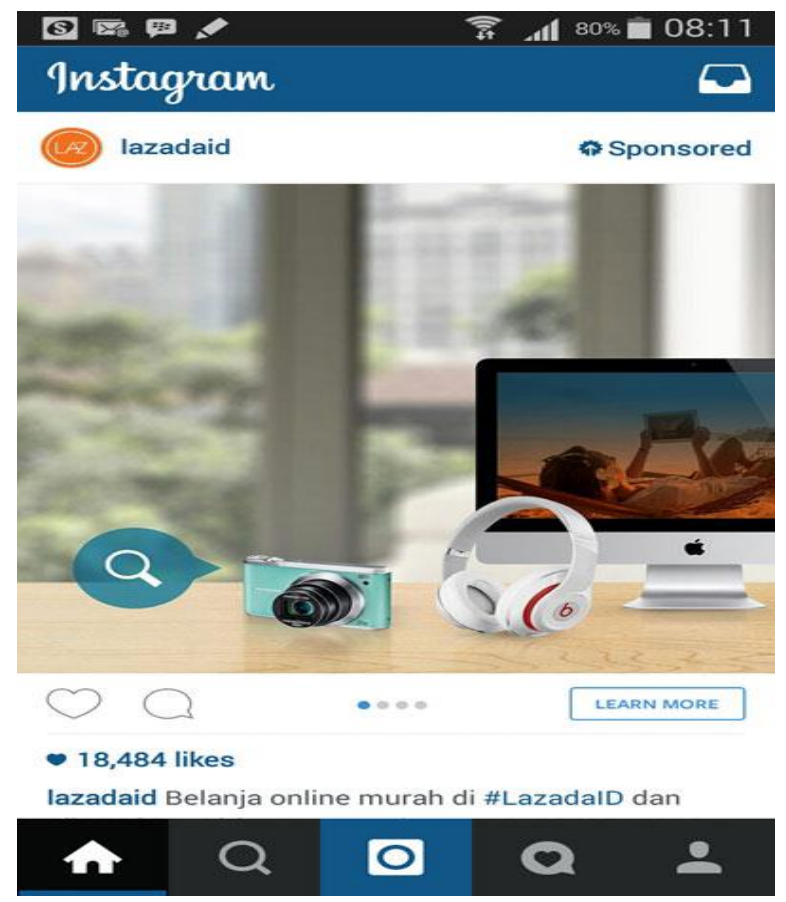

Gambar 4. Iklan Lazada di Instagram

\subsection{Variety of Services}

Beragam layanan dan fitur yang diberikan pada aplikasi m-commerce merupakan strategi yang diterapkan oleh Lazada, Zalora dan Bhinneka dalam menunjang adopsi m-commerce oleh pengguna. Secara umum ketiga layanan m-commerce tersebut memberikan pilihan pembayaran kepada pengguna, sehingga pengguna dapat memilih cara pembayaran yang sesuai dengan kenyamanan pengguna. Pilihan pembayaran tersebut terdiri dari pembayaran menggunakan kartu kredit, kemudian pembayaran dengan cara transfer bank, dan metode pembayaran di tempat atau cash on delivery.

Kemudian terdapat pula layanan cicilan yang disediakan oleh Lazada dan Bhinneka yang bekerjasama dengan beberapa bank terkemuka di Indonesia. Lebih lanjut terdapat pula layanan untuk mengecek status pengiriman pesanan sehingga pengguna $m$-commerce dapat dengan mudah melalukan order tracking untuk mengetahui perkembangan proses pengiriman produk yang dibeli. Status pengiriman produk juga terkirim melalui email dan SMS.

\subsection{Perceived Usefulness}

Terdapat banyak kegunaan dan manfaat yang diberikan kepada pengguna m-commerce Lazada, Zalora dan Bhinneka sebagai strategi untuk menarik minat pengguna mengadopsi aplikasi m-commerce yang disediakan. Salah satu manfaat yang menonjol dari aplikasi m-commerce Lazada dan Zalora adalah terdapat fitur notifikasi yang akan memberitahu pengguna akan adanya informasi mengenai promo dan diskon produk, serta jika terdapat event seperti midnight sale, cash back, dan event promo lainnya. Notifikasi tersebut sangat berguna karena notifikasi akan muncul pada layar mobile device meskipun pengguna tidak sedang menggunakan aplikasi $\mathrm{m}$ commerce tersebut. Sehingga pengguna tidak akan ketinggalan informasi promo dan diskon yang ada.

Lebih lanjut kegunaan dan manfaat yang didapat oleh pengguna adalah kemudahan mengakses dan melakukan transaksi di mana saja dan kapan saja melalui teknologi m-commerce yang diberikan, baik melalui aplikasi maupun melalui mobile web version dari website e-commerce yang ada. Tidak hanya mengakses, tetapi juga memilih dan membeli serta melakukan transaksi melalui sebuah aplikasi $\mathrm{m}$ commerce saja. 


\subsection{Perceived Ease of Use}

Memberikan kemudahan dalam mengakses dan menggunakan teknologi m-commerce merupakan hal yang penting bagi pengguna sehingga mereka memutuskan untuk mengadopsi, mengingat ukuran layar yang kecil dibandingkan jika melakukan transaksi melalui layar desktop. Strategi yang dipakai oleh Lazada, Zalora, dan Bhinneka adalah mendesain tampilan seminimalis mungkin tanpa mengurangi fitur - fitur yang ada sehingga aplikasi $m$-commerce yang disediakan mudah digunakan. Sebagai contoh desain telah dibuat seefisien mungkin untuk memfasilitasi pencarian produk dengan pembagian berdasarkan kategori-kategori yang ada. Hal ini dilakukan dengan menggunakan hidden mеnи yang tidak menyita banyak tempat pada layar, dan baru muncul jika pengguna menekan tombol menu seperti yang terlihat pada gambar 5. Menu tersebut juga memuat beberapa kategori produk seperti kategori Wanita dan Pria serta kategori jenis produk seperti pakaian, sepatu dan aksesoris.

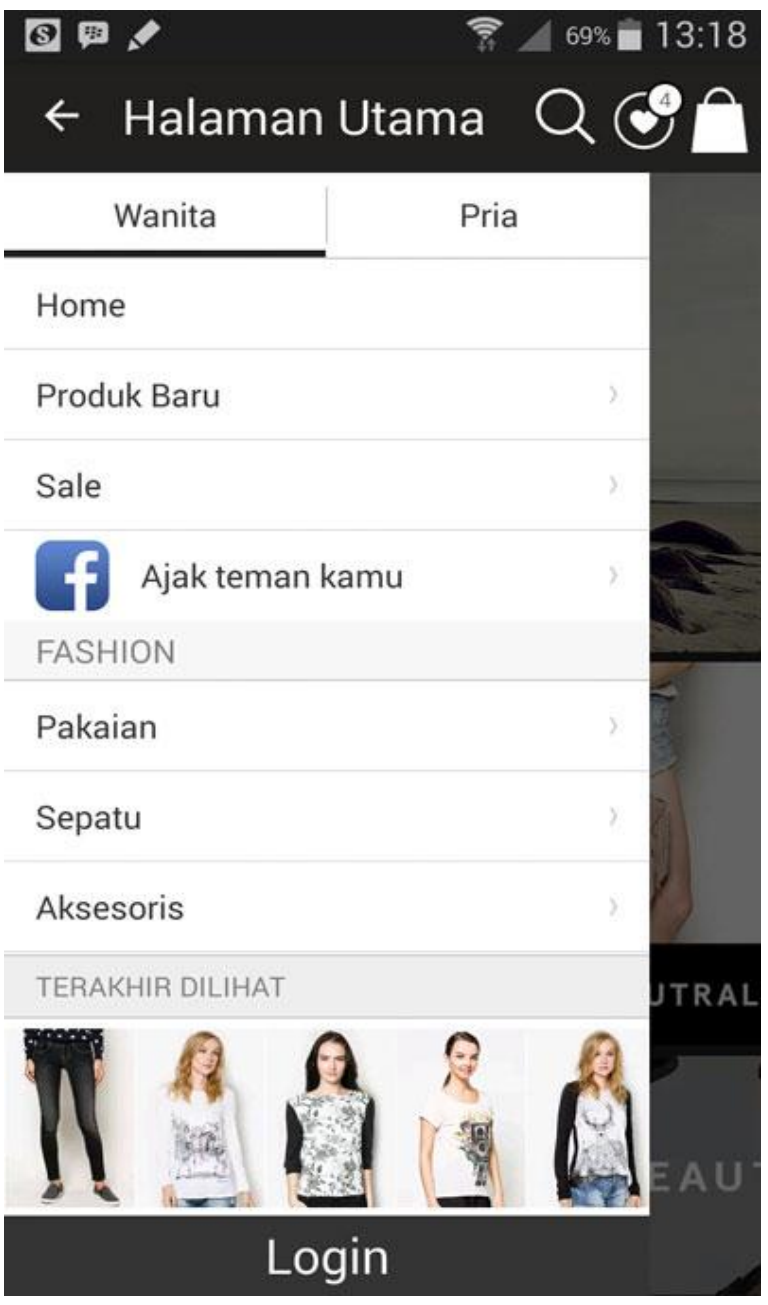

Gambar 5. Hidden Menu Zalora
Selain itu terdapat fitur - fitur lain pada aplikasi yang bertujuan untuk memberikan kemudahan kepada pengguna seperti wishlist di mana pengguna dapat dengan mudah menandai dan menyimpan produk yang mereka sukai untuk dapat diakses dengan mudah di kemudian hari. Kemudian terdapat pula fitur shopping cart, yang berfungsi untuk menyimpan produk-produk yang akan dibeli. Demikian pula untuk memudahkan pengguna melihat tampilan produk secara menyeluruh dari segala sisi, terutama untuk produk fashion, maka disediakan fitur preview produk yang mudah diakses dari layar mobile. Untuk memilih ukuran produk fashion yang sesuai dengan mudah maka disediakan pula panduan ukuran untuk setiap produk beserta ketersediaan produk.

\subsection{Trialability}

Strategi yang digunakan oleh penyedia layanan $m$ commerce untuk menunjang faktor trialability dalam adopsi adalah dengan menyediakan layanan pengembalian produk secara gratis jika pengguna kecewa dengan kualitas produk karena adanya cacat produk ataupun terjadi mallfunction khususnya pada produk elektronik. Tentunya kompensasi yang diberikan adalah penggantian produk atau pengembalian uang. Strategi ini diterapkan baik oleh Lazada, Zalora maupun Bhinneka.

\section{KESIMPULAN}

Penyedia layanan m-commerce B2C di Indonesia telah menerapkan beberapa strategi untuk menunjang faktor adopsi teknologi m-commerce tersebut. Baik Lazada, Zalora, maupun Bhinneka sebagai layanan B2C terpopuler di Indonesia telah mempertimbangkan faktor adopsi trust, cost, social influences, variety of services, perceived usefulness, perceived ease of use, dan triability untuk meningkatkan layanan, menambah fitur aplikasi, dan meraih kepercayaan pengguna sebagai strategi untuk menarik pengguna dalam mengadopsi m-commerce.

Secara umum strategi yang diterapkan adalah menyediakan diskon atau voucher bagi member dan pengguna aplikasi m-commerce, kemudian memberikan garansi keamanan dan kepercayaan dalam bertransaksi yang ditunjang dengan disediakannya pilihan cara membayar dan layanan pengembalian barang, dan beberapa fitur menarik yang memudahkan pengguna aplikasi m-commerce seperti fitur shopping cart,wishlist, panduan ukuran, preview produk. Terdapat pula fitur review dan rating produk dari pembeli sebagai referensi pengguna. Selain itu, 
fitur yang dapat memberikan manfaat yang dapat bagi pengguna aplikasi m-commerce adalah fitur notifikasi, yang akan mengingatkan dan menginformasikan pengguna akan adanya promosi, diskon dan event. Strategi berikutnya adalah mendesain aplikasi $m$ commerce dan mobile friendly version dari website $e$ commerce secara minimalis dan efisien sehingga mudah digunakan dan diakses dari layar mobile yang berukuran lebih kecil dari layar desktop.

\section{DAFTAR REFERENSI}

Chong, A. Y. L., Chan, F. T., \& Ooi, K. B. (2012). Predicting consumer decisions to adopt mobile commerce: Cross country empirical examination between China and Malaysia. Decision Support Systems, 53(1), 34-43. doi:10.1016/j.dss.2011. 12.001.

Davis, F.D. (1989). Perceived usefulness, perceived ease of use, and user acceptance of information technology. MIS Quaterly, 13(3), 319-340. doi: $10.2307 / 249008$

eMarkerter Inc. (2014). Global B2C Ecommerce Sales to Hit \$1.5 Trillion This Year Driven by Growth in Emerging Markets. Retrieved May $7^{\text {th }}, 2015$ from http://www.emarketer.com/ Article/Global-B2C-Ecommerce-Sales-Hit-15Trillion-This-Year-Driven-by-Growth-Emerging-Markets/1010575
Lukman, E. (2014). 18 toko online populer di Indonesia. Retrieved May $7^{\text {th }}, 2015$ from https://id. techinasia.com/toko-online-populer-di-indone$\underline{\text { sial }}$

Oh, J. \& Yoon, S.J. (2014). Validation of Haptic Enabling Technology Acceptance Model (HETAM): Integration of IDT and TAM. Telematics and Informatics, 31(4), 585-596. doi:10.1016/j. tele.2014.01.002

Rogers, E. M. (2010). Diffusion of Innovations (4 $4^{\text {th }}$ ed.). NewYork: The Free Press.

Utami, A. D., \& Triyono, R. A. (2011). Pemanfaatan Blackberry Sebagai Sarana Komunikasi Dan Penjualan Batik Online Dengan Sistem Dropship Di Batik Solo 85. Speed-Sentra Penelitian Engineering dan Edukasi, 3(3), 33-40. Retrieved from http://ijns.org/journal/index.php/speed/ index

yStats.com GmbH \& Co. KG (2015). B2C E-commerce Booming Across Southeast Asia. Retrieved September 10th, 2015 from https://www. ystats.com/b2c-e-commerce-booming-acrosssoutheast-asia/

yStats.com GmbH \& Co. KG (2015). Asia Pacific MCommerce Snapshot 2015. Retrieved September 10th, 2015 from https://www.ystats.com/wpcontent/uploads/2015/03/Product-BrochureOrder-Form Asia-Pacific-M-CommerceSnapshot-2015.pdf 